\title{
REKONSTRUKCJA UNIWERSALNEGO POJECIA ANALOGII W FILOZOFII ŚW. TOMASZA
}

\begin{abstract}
W niniejszym studium przedmiotem analizy uczyniono św. Tomasza z Akwinudoktrynę analogii. Jakkolwiek analogia ma swoje stałe miejsce w filozofii i teologii katolickiej, tak już zgody nie ma w kwestii pojęcia analogii oraz jej roli we wskazanych obszarach wiedzy. Tymczasem analogia nie może być sprawnym narzędziem filozoficznego i teologicznego poznania, dopóki nie wypracuje się jednej spójnej jej interpretacji. O tym jak trudno stworzyć taką interpretację świadczą liczne rozbieżne komentarze i polemiczne studia dotyczące tego zagadnienia. Autor niniejszego studium twierdzi, że najbardziej podstawowym zadaniem w pokonywaniu rozbieżności interpretacyjnych, dotyczących św. Tomasza teorii analogii, jest zadanie określenia uniwersalnego pojęcia analogii. Zmierza on do ustalenia takiego pojęcia poprzez polemiczną dyskusję z zrekonstruowanym pojęciem analogii i wskazywanym,jako uniwersalne przez współczesnego francuskiego tomistę de l'abbé S. Leclère. Twierdzeniem niniejszej pracy jest stanowisko, że Leclère niesłusznie zawęził św. Tomasza teorię analogii jedynie do porządku logicznego czyniąc z niej wyłącznie narzędzie orzekania wspólnych predykatów o przedmiotach. Wykazuje, że św. Tomasz wielokrotnie daje wyraz temu, iż myśli on porządkiem rzeczy poznawanej, dlatego porządek metafizyczny w jego dziełach uprzedza porządek logiczny. W przeciwieństwie do tego, jak robił to l'abbé S. Leclère, rekonstrukcja pojęcia analogii jako takiej winna przebiegać nie w porządku logicznym, lecz w porządku metafizycznym. Natomiast za słuszny uznaje się sprzeciw de Leclère, wobec redukowania, przez Kajetana i komentatorów św. Tomasza podążających za Kajetanem, uniwersalnego pojęcia analogii do jednego z jej typów.

Slowa kluczowe: analogia, analogiczne orzekanie, język, metafizyka, tomizm.
\end{abstract}

\section{WSTEP}

Zagadnienie analogii pojawia się $\mathrm{w}$ kontekście metafizycznego badania pluralizmu bytowego. Chodzi o taki sposób bytowania rzeczy, w którym rzeczy istotnie różnią się między sobą, a w niektórych aspektach są do siebie podobne. W metafizyce jednak mówi się o analogii szerzej, aniżeli tylko w odniesieniu do bytowania rzeczy. Analogiczne bytowanie rzeczy implikuje analogię jako metodę ich poznawania a następnie analogicznego o nich orzekania. Teoria analogii zespalająca wskazane obszary jest dziedzictwem myśli św. Tomasza z Akwinu. I chociaż św. Tomasz nie stworzył traktatu o analogii, to jednak liczne jego wypowiedzi na temat analogii, rozsiane w różnych jego dziełach, świadczą o wadze i znaczeniu jakie ten przypisywał analogii w tworzonym przez siebie systemie filozoficznym. Analogia w tekstach św. Tomasza jest obecna najczęściej wtedy, gdy bada on problemy metafizyczne oraz te z zakresu teologii naturalnej. Spójność jego twierdzeń dotyczących analogii pozwala je nazwać tomistyczną

\footnotetext{
${ }^{1}$ Ks. dr Andrzej Sołtys, Zakład Nauk Humanistycznych, Wydział Zarządzania, Politechnika Rzeszowska, e-mail : asoltys@prz.edu.pl
} 
teorią analogii. Także dla współczesnej filozofii i teologii św. Tomasza doktryna analogii nie przestaje być dziedzictwem o fundamentalnym znaczeniu.

Analiza twierdzeń Akwinaty dotyczących analogii i ich interpretacja nie jest jednak łatwa. Św. Tomasz wypowiada je zawsze przy okazji badania innych zagadnień ${ }^{2}$. O trudności spójnej interpretacji Tomasza teorii analogii świadczą liczne rozbieżne komentarze i polemiczne studia na jej temat. W niniejszej pracy podejmujemy analizę autorskiej interpretacji Tomaszowego uniwersalnego pojęcia analogii, dokonaną przez współczesnego francuskiego tomistę l'abbé S. Leclère. Twierdzimy, że rekonstrukcja pojęcia analogii jako takiej jest nie tylko kluczem do właściwego rozumienia poszczególnych odmian analogii, wokół których narosło tak dużo błędów, ale także do określenia ich właściwej roli w metafizyce klasycznej. Celem niniejszego studium jest zbadanie, dokonanej przez de l'abbé S. Leclère, autorskiej rekonstrukcji Tomaszowego uniwersalnego pojęcia analogii pod kątem jej zgodności z całościową jego doktryną analogii. L'abbé S. Leclère bada pojęcie analogii jako takiej w związku z dyskutowanym przez św. Tomasza problemem analogicznego orzekania tych samych nazw o wielu rzeczach. Tomista utrzymuje, że pojęcie analogii jako takiej przynależy do porządku logicznego, a jakiekolwiek wychodzenie poza ten porządek, w poszukiwaniu uniwersalnego pojęcia analogii, będzie w jego przekonaniu zawsze chybione. Pokazuje droge rozwiązania, jak twierdzi, pozornych sprzeczności w tekstach św. Tomasza, dotyczących najbardziej ogólnego pojmowania analogii.

\section{ANALOGIA NAZW JAKO KONTEKST ODKRYCIA} UNIWERSALNEGO POJECIA ANALOGII

Znaczenie problemu analogii $\mathrm{w}$ filozofii i teologiiśw. Tomasza została zauważona przez licznych jego komentatorów klasycznych, tudzież neotomistycznych ${ }^{3}$. L'abbé S. Leclère uznaje winnymi komentatorów pism św. Tomasza za to, że ich komentarze dotyczące analogii nie tylko, że nie odpowiadają filozoficznej myśli św. Tomasza, lecz się jej wręcz przeciwstawiają. Chodzi tu głównie o tych komentatorów, którzy w interpretacji Tomaszowego zagadnienia analogii postępują za Kajetanem. Zdaniem Leclère, oni mało, że odeszli od samej istoty analogii, co zaczęli wkładać $w$ usta św. Tomaszowi twierdzenia dotyczące analogii, które przeciwstawiają się jego całościowej myśli filozoficznej ${ }^{4}$. Z tej racji rodzi się poniekąd potrzeba upomnienia się, aby św. Tomaszowi nie przypisywać tego, czego na temat analogii nigdy nie powiedział. $\mathrm{Z}$ pewnością komentator może uznać, że w jakimś twierdzeniu o analogii św. Tomasz sie pomylił, ale jest on w obowiązku określić, czego ta pomyłka dotyczy. Bez wskazania takich racji winien był zachować oryginalną myśl Akwinaty. A zachowałby ją wówczas, gdyby interpretował jego teksty zachowując literę zawartych tam twierdzeń. Jest to bowiem jedyny sposób, aby dogłębnie poznać Tomaszową teorię analogii twierdzi Leclère ${ }^{5}$.

\footnotetext{
${ }^{2}$ Por. M. A. Krąpiec, Teoria analogii bytu, RW KUL, Lublin 1993, s.307.

${ }^{3}$ Spośród klasycznych komentatorów teorii analogii św. Tomasza na szczególną uwagę zasługuje Kajetan i Franciszek Sylwestris z Ferrary, bowiem współcześni tomiści w interpretacji teorii analogii św. Tomasza, najczęściej podążają szlakiem jednego, bądź drugiego.

4 Por. Abbé S. Leclère, A propos de l'analogie chez saint Thomas d'Aquin [online], http://www.salve-regina.com/salve/L\%27analogie (30.02.2015).

${ }^{5}$ Por. ibidem.
} 
Św. Tomasz myśli porządkiem rzeczy, które bada ${ }^{6}$. Natomiast analogia nie należy do porządku rzeczy, lecz istnieje między różnymi sensami tej samej nazwy i wówczas nazwa nie jest ani jednoznaczna ani wieloznaczna. Leclère wskazuje na tekst św. Tomasza $D e$ Potentia Dei, który jak twierdzi, dobrze uwyraźnia charakter analogicznego orzekania. W tym tekście św. Tomasz bada orzekanie analogicznych nazw ojcostwo i synostwo ${ }^{7}$. Chociaż ojcostwo i synostwo w porządku bytowym pierwotnie istnieje w Bogu, gdyż Bóg jest źródłem wszelkiego ojcostwa, to jednak nazywamy Boga Ojcem a Chrystusa Synem przenosząc nazwę ojca i syna z porządku relacji ludzkich. Per prius nazwę ojcostwo orzeka się o ojcostwie ludzkim, natomiast per posterius o ojcostwie Boga Ojca. W analogicznej więc denominacji spełnia się ratio analogiae. Analogia jest istotnie sprawą nazw, nie natomiast rzeczy, które są analogiczną nazwą oznaczane ${ }^{8}$. Nie można zatem mylić tego, co odnosi się do nazwy i tego, co odnosi się do rzeczy twierdzi tomista. W podobnym duchu wypowiada się inny współczesny tomista Owen, który odróżnia pierwszeństwo naturalne od pierwszeństwa wśród znaczeń nazwy i wskazuje na pierwszeństwo wśród znaczeń nazwy jako pierwszeństwo o znaczeniu centralnym dla analogii ${ }^{9}$. Przenoszenie nazw $\mathrm{z}$ jednych rzeczy na inne dokonuje się $\mathrm{w}$ oparciu o dostrzeżone podobieństwo, bądź prosty stosunek zachodzący między rzeczą oznaczoną nazwą per prius i inną rzeczą, której przydzielamy tę samą nazwę na podstawie zachodzącego podobieństwa, bądź stosunku. Leclère twierdzi, że wspomniane podobieństwo, bądź stosunek między rzeczami stanowią warunek po stronie rzeczy, aby z kolei po stronie nazwy analogia działała.

Jednakże to nie podobieństwo między dwoma rzeczami rozstrzyga o analogii między dwoma nazwami ${ }^{10}$. Jeśli badając analogię zatrzymamy się na podobieństwie, które przynależy do porządku bytowego, to tym samym opuścimy dziedzinę analogii jako takiej. Leclère twierdzi, że według Tomasza warunkiem analogii po stronie rzeczy nie jest jakiś zdeterminowany rodzaj podobieństwa. Otóż podobieństwo może być realne, osadzone na przyczynowości, bądź tylko wyobrażone, jak ma to miejsce w przypadku metafory. Skoro więc rodzaj podobieństwa jest bez znaczenia dla analogii jako takiej, to dowodzi tego, że analogia nie zachodzi po stronie rzeczy. Dla potwierdzenia słuszności tego przekonania Leclère wskazuje na tekst In Boetii de Trinitate ${ }^{11}$. Św. Tomasz

\footnotetext{
${ }^{6}$ „Toujours saint Thomas a pensé l'ordre des réalités qu'il considérait”. Ibidem.

${ }^{7}$ „Praeterea, licet secundum rem paternitas et filiatio per prius sit in deo quam in nobis, secundum illud apostoli ad Ephes. III, 15: ex quo, scilicet deo patre, omnis paternitas in caelo et in terra nominatur; tamen secundum nominis impositionem haec nomina translate sunt ab humanis ad divina". Św. Tomasz z Akwinu, De Potentia Dei, q. 10, a. 4.

${ }^{8}$ „On voit que l'analogie est essentiellement le fait du nom, et non de la chose qu'il désigne”. Abbé S. Leclère, op. cit; ; Ralph McInerny twierdzi, że św. Tomasz wykorzystuje łaciński termin analogia, aby mówić o porządku pomiędzy znaczeniami w używaniu wspólnego terminu. Por. R. McInerny, Aquinas and Analogy, The Catholic University of America Press, Washington, 1996, s. 154. Odmienne stanowisko prezentuje Anderson. W swojej pracy twierdzi, że pierwszorzędnie analogia dotyczy porządku bytowego. Zob. J. F. Anderson, Reflections on the analogy of being, Martinus Nijhoff, The Hague 1967.

${ }^{9}$ Por. G. E. L. Owen, Logic, Science and Dialectic, Cornell University Press, Ithaca 1986, s. 192193.

${ }^{10}$ "Ce n'est pas cette ressemblance qui constitue formellement l'analogie”. Abbé S. Leclère, op. cit.

${ }^{11}$ "Sicut autem uniuscuiusque determinati generis sunt quaedam communia principia quae se extendunt ad omnia principia illius generis, ita etiam et omnia entia, secundum quod in ente
} 
utrzymuje w nim, że zasady bytu są zasadami wielu bytów i to one stanowią podstawę orzekania o nich wspólnej nazwy. Orzekać można wspólną nazwę o rzeczy na podstawie wspólnej formy, która jest formą dla wszystkich form, bądź w oparciu o zależność orzekanej treści od przyczyny Analogicznie orzeka się więc nie tylko w oparciu o wzajemne podobieństwo rzeczy, lecz także na podstawie innego typu relacji, stąd nie można mówić o analogii pomiędzy rzeczami, która implikowałaby z kolei analogię orzekania. Leclère niesłusznie wykorzystał przytoczony tekst św. Tomasza dla wzmocnienia uznanego podstawowego twierdzenia, iż analogia jest w swej istocie sprawą nazw.

Tymczasem św. Tomasz nie mówi w In Boetii de Trinitate, że analogia istnieje między nazwami, jak tylko, że orzekać można wspólną nazwę na podstawie podobieństwa, bądź przyczynowego stosunku zależności między rzeczami. Leclère wyprowadził z tego tekstu jak się wydaje zbyt daleko idący wniosek, że istotnie analogia jest sprawą nazw, a nie rzeczy, których te nazwy dotyczą oraz, że wyróżnienie różnych form podobieństwa nie prowadzi do różnych form analogii ${ }^{12}$. Na podstawie tego, co powiedziano Leclère nie wiąże analogii $\mathrm{z}$ realnym bytem. Według niego podobieństwo realne, bądź tylko wyobrażone pomiędzy rzeczami nie konstytuuje analogii. Podobieństwo między realnymi rzeczami może być jedyną $\mathrm{z}$ możliwych, aczkolwiek niekoniecznych podstaw do analogicznego orzekania wspólnych nazw o wielu rzeczach. Leclère natomiast zupełnie pominął kwestię analogii bytu ${ }^{13}$, o której explicite mówi św. Tomasz w podstawowym tekście zawierającym podział analogii ${ }^{14}$. Analizuje tylko te teksty św. Tomasza, które fundują podstawę dla teorii analogii orzekania. I tylko analogia nazw tworzy jego zdaniem właściwy kontekst dla wypracowania św. Tomasza uniwersalnego pojęcia analogii.

\section{SPOSOBY ANALOGICZNEGO ORZEKANIA NAZW}

Św. Tomasz mówi o kilku sposobach analogicznego orzekania nazw w Summach oraz w traktacie De Veritate. W Summa Theologiae I, q. 13, a. 5 św. Tomasz zmierza do rozstrzygnięcia, czy to, co orzekamy o Bogu i stworzeniach, orzekamy o nich jednoznacznie $^{15}$. Odsuwa błędne odpowiedzi, a mianowicie, że orzekanie o Bogu i

communicant, habent quaedam principia quae sunt principia omnium entium. Quae quidem principia possunt dici communia dupliciter secundum Avicennam in sua sufficientia: uno modo per praedicationem, sicut hoc quod dico: forma est commune ad omnes formas, quia de qualibet praedicatur; alio modo per causalitatem, sicut dicimus solem unum numero esse principium ad omnia generabilia. Omnium autem entium sunt principia communia non solum secundum primum modum, quod appellat philosophus in XI metaphysicae omnia entia habere eadem principia secundum analogiam, sed etiam secundum modum secundum". Św. Tomasz z Akwinu, In Boetii de Trinitate, p. 3, q. 5 , a. 4.

${ }^{12}$ „Distinguer les différentes formes de resemblance n'est donc pas distinguer les différentes formes d'analogie". Abbé S. Leclère, op. cit.

${ }^{13}$ Współczesny tomista Bernard Montagnes w swej pracy wykazuje gruntownie, że pojęcie analogii jako takiej dotyczy porządku bytowego. Zob. B. Montagnes, La doctrine de l'analogie de l'être d'après saint Thomas d'Aquin, Publications Universitaires, Louvain 1963.

${ }^{14}$ Sw. Tomasz z Akwinu, In I Sent. d.19, q.5, a. 2, ad 1.

${ }^{15}$ „Dicendum est igitur quod huiusmodi nomina dicuntur de deo et creaturis secundum analogiam, id est proportionem. Quod quidem dupliciter contingit in nominibus, vel quia multa habent proportionem ad unum, sicut sanum dicitur de medicina et urina, inquantum utrumque habet 
stworzeniach jest jednoznaczne, bądź wieloznaczne. Zdaniem św. Tomasza o Bogu i stworzeniach orzeka się nazwy wedle analogii, czyli proporcji. Dokonuje się tego na dwa sposoby. Według pierwszego sposobu orzeka się wspólną nazwę o wielu rzeczach wtedy, gdy te są proporcjonalne do czegoś jednego multa habent proportionem ad unum. Św. Tomasz ilustruje ten sposób orzekaniem nazwy zdrowy o lekarstwie i o moczu, gdy każde z nich jest podporządkowane i proporcjonalne do zdrowia zwierzęcia, którego pierwsze jest przyczyną, a drugie znakiem. Drugi sposób orzekania ma miejsce wtedy, gdy rzeczy o których orzekamy nazwę są do siebie proporcjonalne ex eo quod unum habet proportionem ad alterum. Na przykład nazwa zdrowy jest orzekana o lekarstwie i o zwierzęciu, gdy lekarstwo jest przyczyną zdrowia będącego własnością zwierzęcia. I to właśnie w ten ostatni sposób, zdaniem św. Tomasza, analogicznie orzeka się niektóre predykaty o Bogu i stworzeniach. Nie jest to orzekanie ani jednoznaczne, ani wieloznaczne, lecz orzekanie według analogii, czyli proporcji secundum analogiam, id est proportionem. Orzekanie o Bogu i stworzeniach zakłada zależność stworzenia od Boga jako zasady i przyczyny, w której istnieją uprzednio wszystkie doskonałości rzeczy. Analogia jest osadzona na istniejącym stosunku między stworzeniem i Bogiem.

W kolejnej kwestii św. Tomasz wskazuje na naturę analogicznego orzekania nazw ${ }^{16}$. Zwraca uwagę, że jeśli coś orzeka się analogicznie o wielu rzeczach, to znaczy, że to coś zgodnie $\mathrm{z}$ właściwym mu pojęciem, znajduje się w czymś jednym, od czego pozostałe rzeczy biorą nazwę illud invenitur secundum propriam rationem in uno eorum tantum, a quo alia denominantur. Akwinata także ten sposób orzekania analogicznych nazw unaocznia przykładem orzekania nazwy $z$ drowy ${ }^{17}$ i zauważa, że tę nazwę orzekamy o zwierzęciu, lekarstwie i urynie, ale nie dlatego, że zdrowie jest tylko w zwierzęciu, lecz jedynie mając na myśli to, że od zdrowia zwierzęcia zdrowym nazywa się lekarstwo, ponieważ lekarstwo przywraca zdrowie, zdrowa nazywamy urynę, gdy jest oznaką zdrowia. Wprawdzie zdrowie nie jest ani w lekarstwie, ani w urynie, ale w jednym $\mathrm{i}$ drugim jest coś, co zdrowie powoduje, bądź je oznacza. Powyższy przykład doprecyzowuje podstawę analogicznego orzekania. Otóż o lekarstwie i urynie orzeka się predykat zdrowy, ponieważ $\mathrm{w}$ obydwu tych rzeczach znajduje się pewna treść, która koresponduje $\mathrm{Z}$ treścią ujmowaną właściwym pojęciem. Treść korespondująca $\mathrm{Z}$ właściwym pojęciem wzbogaca to pojęcie. Znaczy to, że przez orzekanie tego predykatu o

ordinem et proportionem ad sanitatem animalis, cuius hoc quidem signum est, illud vero causa; vel ex eo quod unum habet proportionem ad alterum, sicut sanum dicitur de medicina et animali, inquantum medicina est causa sanitatis quae est in animali. Et hoc modo aliqua dicuntur de deo et creaturis analogice, et non aequivoce pure, neque univoce". Św. Tomasz z Akwinu, Summa Theologiae I, q. 13, a. 5.

${ }^{16}$ „Sed quando aliquid dicitur analogice de multis, illud invenitur secundum propriam rationem in uno eorum tantum, a quo alia denominantur. Sicut sanum dicitur de animali et urina et medicina, non quod sanitas sit nisi in animali tantum, sed a sanitate animalis denominatur medicina sana, inquantum est illius sanitatis effectiva, et urina, inquantum est illius sanitatis significativa. Et quamvis sanitas non sit in medicina neque in urina, tamen in utroque est aliquid per quod hoc quidem facit, illud autem significat sanitatem". Św. Tomasz z Akwinu, Summa Theologiae I, q. 16, a. 6 .

${ }^{17}$ Nazwa jest to wyraz albo wyrażenie, które nadaje się na podmiot lub orzecznik orzeczenia imiennego w zdaniu. Orzeczenie imienne to orzeczenie stwierdzające o podmiocie, że jest on taki a taki: x jest zdrowy. Por. Z. Ziembiński, Logika praktyczna, Wydawnictwo PWN, Warszawa 1994, s. 26. 
innych rzeczach orzekamy bogatszą treść, aniżeli tę, która jest w pojęciu właściwym, a jeszcze ściślej nie orzekamy treści pojęcia właściwego, ale treść $\mathrm{z}$ tą ostatnią $\mathrm{w}$ różny sposób powiązaną.

W Summa contra Gentiles św. Tomasz mówi o analogicznym orzekaniu, które dokonuje się na dwa sposoby ${ }^{18}$. Pierwszy, gdy wiele rzeczy otrzymuje tę samą nazwę ze względu ich stosunek do jakieś jednej rzeczy - do całości. Przykładem tego jest orzekanie nazwy zdrowy o wielu, przy czym właściwe pojęcie zdrowy orzeka się tylko o zwierzęciu. Natomiast drugi sposób orzekania zachodzi wówczas, gdy nazwę oznaczającą jakąś rzecz orzekamy o innej rzeczy powiązanej z pierwszą stosunkiem zależności. Przykładem takiego orzekania jest rozciągnięcie nazwy byt z substancji, na przypadłość, która nie może bez substancji istnieć. W tym przypadku substancja i przypadłość nie pozostają w stosunku do czegoś trzeciego non quod substantia et accidens ad aliquid tertium referantur, lecz nazwę byt orzeka się o przypadłości na podstawie jej stosunku zależności od substancji sicut ens de substantia et accidente dicitur secundum quod accidens ad substantiam respectum habet. Wyżej zanalizowane teksty św. Tomasza dobrze korespondują ze sobą. W oparciu o nie można wskazać na kilka odmian analogii orzekania. I to na ich podstawie Leclère dąży do skonstruowania uniwersalnego pojęcia analogii.

$\mathrm{Z}$ tymi tekstami zamieszczonymi w Summach zdaje się nie korespondować wypowiedź na temat analogii zamieszczona w De Veritate, gdzie św. Tomasz rozpatruje zagadnienie analogii w kontekście różnoznacznego orzekania nazw o Bogu i stworzeniach $^{19}$. Wskazuje na dwa rodzaje analogii nazw: analogię proporcji (stosunku) $\mathrm{i}$ analogię proporcjonalności prima ergo convenientia est proportionis, secunda autem proportionalitatis. Orzekanie przez analogię jest zawsze orzekaniem według proporcji secundum analogiam, quod nihil est dictu quam secundum proportionem. Pierwszy sposób analogicznego orzekania, to znaczy według analogii proporcji (stosunku), Tomasz definiuje następująco Quia ergo in his quae primo modo analogice dicuntur, oportet esse aliquam determinatam habitudinem inter ea quibus est aliquid per analogiam commune, impossibile est aliquid per hunc modum analogiae dici de deo et creatura ${ }^{20}$. Analogia zasadza się na określonym związku między rzeczami, dla których jest coś analogicznie wspólne. Z tego względu Leclère nazywa ją analogią stosunku l'analogie de rapport ${ }^{21}$. Tomasz utrzymuje, iż według tej analogii nic nie możemy orzekać o Bogu i stworzeniach. Nie jest możliwym, aby mówić o Bogu i stworzeniu według sposobu, gdzie o dwóch rzeczach orzeka się tę samą nazwę, ze względu na coś, co jest w tych rzeczach wspólne, czyli według analogii stosunku secundum analogiam, id est proportionem. Powyższa

\footnotetext{
${ }^{18}$ „Analogice: hoc est, secundum ordinem vel respectum ad aliquid unum. Quod quidem dupliciter contingit: uno modo, secundum quod multa habent respectum ad aliquid unum: sicut secundum respectum ad unam sanitatem animal dicitur sanum ut eius subiectum, medicina ut eius effectivum, cibus ut conservativum, urina ut signum. Alio modo, secundum quod duorum attenditur ordo vel respectus, non ad aliquid alterum, sed ad unum ipsorum: sicut ens de substantia et accidente dicitur secundum quod accidens ad substantiam respectum habet, non quod substantia et accidens ad aliquid tertium referantur". Św. Tomasz z Akwinu, Summa contra Gentiles I, 34

${ }^{19}$ Sw. Tomasz z Akwinu, De Veritate q. 2, a. 11.

${ }^{20}$ Ibidem.

${ }^{21}$ Abbé S. Leclère, op. cit.
} 
charakterystyka analogii proporcji (stosunku) zdaje się przeczyć temu, co na temat zastosowania tej analogii św. Tomasz zapisał w Summa Theologiae I, q. 13, a. 5.

Gdy chodzi o analogię proporcjonalności to św. Tomasz definiuje ją następująco convenientia etiam quandoque attenditur non duorum ad invicem inter quae sit proportio sed magis duarum ad invicem proportionum, sicut senarius convenit cum quaternario ex hoc quod sicut senarius est duplum ternarii, ita quaternarius binarii ${ }^{22}$. Analogia proporcjonalności jest proporcjonalnością proporcji występującej w dwóch jej członach. Przykładem zachodzącej proporcjonalności jest podwojenie $\frac{2}{3}=\frac{4}{6}$. Orzekanie według analogii proporcjonalności jest prezentowane przez Kajetana i komentatorów św. Tomasza podążających za Kajetanem jako jedyny sposób orzekania tej samej nazwy o Bogu i stworzeniu ${ }^{23}$. Jak zatem rozwiązać problem braku spójności w tekstach św. Tomasza dotyczących analogii nazw? Która $\mathrm{z}$ przedstawionych odmian analogii daje odpowiednie podstawy do skonstruowania najbardziej uniwersalnego pojęcia analogii? Czy rzeczywiście św. Tomasza uniwersalne pojęcie analogii jest związane tylko z porządkiem orzekania?

\section{W KIERUNKU UNIWERSALNEGO POJECIA ANALOGII}

Leclère przebadał cztery teksty św. Tomasza, które uznał za najważniejsze dla wykładu jego doktryny analogii. Utrzymuje, że w oparciu o te teksty można zrekonstruować uniwersalne pojęcie analogii. Zresztą czyni to jak się wydaje pod wyraźnym wpływem Kajetana, który właśnie w oparciu o wspomniane teksty badał, które pojęcie analogii można uznać za najbardziej uniwersalne, to znaczy definiujące analogię jako taką. Zaznaczmy przy tym, że Leclère dobierając wypowiedzi św. Tomasza na temat analogii $\mathrm{z}$ góry założył, że najbardziej uniwersalne pojęcie analogii jest zawarte $\mathrm{w}$ analogii nazw. Stąd rozpatrując doktrynę analogii nazw będzie można określić, które pojęcie definiuje analogię jako taką obecną w każdym typie analogii. Francuski tomista zauważa przy tym, że to, co św. Tomasz zawarł w Summa Theologiae I, q. 13, a. 5; Summa Theologiae I, q. 16, a. 6; Summa contra Gentiles I, 34 wydaje się nie korespondować z tym, co powiedział św. Tomasz o analogii w De Veritate q. 2, a. 11. Na pierwszy rzut oka zanalizowane teksty nie są spójne. Podczas gdy to ich spójność jest warunkiem odpowiedniej rekonstrukcji Tomasza uniwersalnego pojęcia analogii.

Leclère prezentuje rozwiązanie tej trudności $\mathrm{w}$ dyskusji z Kajetanem ${ }^{24}$. W swoim traktacie De nominum analogia ${ }^{25}$ Kajetan rozważa, co Tomasz powiedział na temat analogii w De Veritate q. 2, a. 11. Twierdził, że z wszystkich tekstów św. Tomasza traktujących o analogii, doktryna analogii proporcjonalności wyłożona w tym tekście dostarcza najbardziej uniwersalnego i prawdziwego pojęcia analogii ${ }^{26}$. Orzekanie $\mathrm{w}$ tej

\footnotetext{
${ }^{22}$ Św. Tomasz z Akwinu, De Veritate q. 2, a. 11.

${ }^{23}$ Por. R. McInerny, op. cit., s. 15-16.

${ }^{24}$ Zob. A. Krause, Zur Analogie bei Cajetan und Thomas von Aquin: eine Analyse, Halle/Saale, Hallescher1999.

${ }^{25}$ Cajetan, Scripta philosophica: De nominum analogia, Inst. "Angelicum", Romae 1952.

${ }^{26}$ Kajetan wskazuje na trzy odmany anlogii: „Ad tres ergo modos analogiae omnia analoga reducuntur: scilicet ad analogiam inaequalitatis, et analogiam attributionis, et analogiam proportionalitatis. Quamvis secundum veram vocabuli proprietatem et usum Aristotelis, ultimus modus tantum analogiam constituat, primus autem alienus ab analogia omnino sit”. Cajetan, op. cit.
} 
analogii zasadza się bowiem na wewnętrznej denominacji każdego analogatu twierdzi Kajetan. Tym twierdzeniem Kajetan zaprzeczył temu, co św. Tomasz utrzymywał na temat analogii w Summa Theologiae I, q. 13, a. 5; Summa Theologiae I, q.16, a. 6; Summa conra Gentiles I, 34, a mianowicie, że wewnętrzny, bądź zewnętrzny charakter denominacji jest obojętny dla samej analogii. Z kolei wbrew temu, co twierdzi Kajetan, słusznie zauważa Leclère, że św. Tomasz w De Veritate q. 2, a. 11 nie twierdzi, iż analogia proporcji (stosunku) nie jest prawdziwą analogią, lecz tylko podważa, że w oparciu o ten typ analogii można orzekać wspólną nazwę o Bogu i stworzeniu. Natomiast rzekomą niespójność porównywanych tekstów św. Tomasza o analogii Leclère tłumaczy tym, iż użyte przez św. Tomasza słowo proportio w porównywanych tekstach występuje w dwóch odmiennych znaczeniach ${ }^{27}$. W Summa Theologiae i Summa conra Gentiles słowo proportio oznacza stosunek, który realnie nie determinuje dwóch terminów relacji i na podstawie takiego stosunku można wówczas orzekać tę samą nazwę o Bogu i stworzeniu. Bóg bowiem w tym stosunku nie jest zdeterminowany przez stworzenie, jest całkowicie wolny w stosunku do świata. Inaczej świat, który w istnieniu jest zdeterminowany stałą zależnością od Boga.

Inny sens ma natomiast słowo proportio w De Veritate q. 2, a. 11. Słowo proportio oznacza w tym tekście stosunek, który realnie determinuje obydwa jego korelaty, i to stosuje się do dwóch odmian analogii występujących w tym tekście. Z tego względu według analogii proporcji (stosunku) nie można orzekać tej samej nazwy o Bogu i stworzeniu, gdyż pomiędzy Bogiem i stworzeniem nie istnieje stosunek, który determinowałby obydwa korelaty. Co się tyczy analogii proporcjonalności, to Kajetan uznał ją za jedynie prawdziwą analogię, według której można orzekać tę samą nazwę o Bogu i stworzeniu. Na tym etapie można się zgodzić z Kajetanem jedynie w tym, że według analogii proporcjonalności możemy orzekać o Bogu i stworzeniu, o ile zinterpretujemy odpowiednio stosunki współtworzące strukturę tej analogii. Otóż w tej analogii proporcja determinująca obydwa korelaty może zachodzić jedynie wewnątrz poszczególnych korelatów, nie natomiast między korelatami współtworzącymi analogię proporcjonalności. W przeciwnym razie tak samo jak i w analogii proporcji (stosunku) $\mathrm{z}$ De Veritate stosunek determinowałby obydwa korelaty, co uniemożliwiłoby stosowanie tej analogii do orzekania o Bogu i stworzeniu.

Występowanie w dwóch znaczeniach słowa proportio Leclère argumentuje wskazując na liczne inne wypowiedzi św. Tomasza. O dwóch znaczeniach terminu proportio Akwinata mówi explicite w kilku miejscach ${ }^{28}$.W pierwszym znaczeniu proportio oznacza pewien stosunek - odniesienie jednej ilości do drugiej. W innym znaczeniu każdy stosunek jednego do drugiego jest nazywany proportio. I w tym sensie pozostają

nr 3; Zob. J. Hochschild, The Semantics of Analogy Reading Cajetan's De Nominum Analogia, University of Notre Dame Press, Indiana 2010

${ }^{27}$ „En fait la différence entre tous les textes des deux sommes sur l'analogie et le De Veritate q.2, a.11, est que le sens du mot proportio n'est pas le même". Abbé S. Leclère, op. cit.

${ }^{28}$ „Proportio dicitur dupliciter. Uno modo, certa habitudo unius quantitatis ad alteram; secundum quod duplum, triplum et aequale sunt species proportionis. Alio modo, quaelibet habitudo unius ad alterum proportio dicitur. Et sic potest esse proportio creaturae ad deum, inquantum se habet ad ipsum ut effectus ad causam, et ut potentia ad actum. Et secundum hoc, intellectus creatus proportionatus esse potest ad cognoscendum deum”. Św. Tomasz z Akwinu, Summa Theologiae I, q. 12 , a. 1, ad 4 . 
stworzenia w proporcjonalnym stosunku do Boga, jako skutek do swojej przyczyny, bądź możność do aktu. $\mathrm{O}$ tych dwóch znaczeniach słowa proportio św. Tomasz mówi także w III Sent ${ }^{29}$. Niniejsza wypowiedź na temat dwojakiego pojmowania stosunku każe zwrócić uwagę na fakt, że w przypadku rozumienia proportio jako stosunku jednego do drugiego trzeba odróżnić dwie jego odmiany, czego z kolei zdaje się nie dostrzegać Leclère. Jedną jest fundujący analogię proporcji stosunek, który determinuje obydwa korelaty, jak ma to miejsce w przypadku stosunku między materią i formą, inną gdy stosunek nie determinuje korelatów, jak to jest $\mathrm{z}$ kolei $\mathrm{w}$ przypadku analogii proporcji (stosunku) opisanej $\mathrm{w}$ Summach, według której orzeka się tę samą nazwę o Bogu i o stworzeniu.

Kajetan w De nominum analogia interpretując pojęcie analogii opisane w De Veritate q. 2, a. 11 nie zauważa wskazanych wyżej znaczeń słowa proportio. Zdaniem Kajetana w De Veritate św. Tomasz zawarł najbardziej uniwersalne i prawdziwe pojęcie analogii. Należy zauważyć, że słowa proportio $\mathrm{w}$ tym traktacie św. Tomasz używa w węższym znaczeniu. Proportio oznacza stosunek, który determinuje obydwa korelaty. Zdaniem de Leclère ograniczone znaczenie słowa proportio nie może stanowić podstawy dla utworzenia definicji najbardziej uniwersalnego pojęcia analogii. Według niego takie pojęcie Akwinata zawarł w dwóch Summach, gdzie określił najogólniejsze warunki analogicznego orzekania. Orzekamy wspólną analogiczną nazwę o wielu rzeczach dlatego, że o jednej $\mathrm{z}$ tych rzeczy orzekamy zgodnie $\mathrm{z}$ właściwym jej pojęciem orzekamy o formie tej rzeczy i od tej rzeczy inne biorą nazwę. Uszczegółowienie tego najbardziej uniwersalnego pojęcia analogii prowadzi, zdaniem współczesnego tomisty, do wyróżnienia odmian analogii, a te $\mathrm{z}$ kolei takie najbardziej ogólne pojęcie analogii zakładają. Według Leclère najogólniejsze teksty św. Tomasza nie zezwalają fundować analogii jedynie na podobieństwie dwóch stosunków i wewnętrznej denominacji każdego analogatu. Skoro więc pojęcie analogii zawarte w De Veritate zasadza się wyłącznie na takim podobieństwie i takiej denominacji, to nie można uznać tego pojęcia analogii za najbardziej uniwersalne.

L'abbé Leclère krytykuje tych filozofów tomistycznych, którzy idąc za Kajetanem nie badają rozszerzonego pojęcia analogii ukazanego w Summach, to znaczy pojęcia uniwersalnego. Także szczegółowe rozróżnienia związane $\mathrm{z}$ wykładem pojęcia analogii, jakie św. Tomasz zawarł w De Veritate q. 2, a. 11, zostały przez nich źle zinterpretowane i bezpodstawnie uznane za racje uniwersalnej definicji analogii. Przykładu takiej interpretacji Tomaszowego pojęcia analogii, zawartego w Summa Theologiae I, q.16, a. 6, dostarcza Antoine Goudin, który pisze Analoga attributionis sunt, quorum unum participat rationem communem cum habitudine ad aliud principalius $^{30}$. Natomiast analogię proporcjonalności charakteryzuje następująco analoga proportionalitatis sunt, quae se habent ad rationem communem cum quaedam proportione. Według Goudina

\footnotetext{
${ }^{29}$ „Proportio dicitur dupliciter. Uno modo idem est proportio quod certitudo mensurationis duarum quantitatum: et talis proportio non potest esse nisi duorum finitorum, quorum unum excedit secundum aliquid certum et determinatum. Alio modo dicitur proportio habitudo ordinis, sicut dicimus esse proportionem inter materiam et formam, quia se habet in ordine, ut perficiatur materia per formam, et hoc secundum proportionabilitatem quamdam: quia sicut forma potest dare esse, ita et materia potest recipere idem esse: et hoc modo etiam movens et motum debent esse proportionabilia, et agens et patiens, ut scilicet sicut agens potest imprimere aliquem effectum, ita patiens possit recipere eumdem".Św. Tomasz z Akwinu, III Sent. d. 1, q. 1, a. 1.

${ }^{30}$ Cyt. za Abbé S. Leclère, op. cit.
} 
analogiami atrybucji są te, w których tylko jedna rzecz uczestniczy w sensie właściwym we wspólnym pojęciu, natomiast analogiami proporcjonalności, w których korelaty są powiązane z sobą wspólną treścią w pewnej proporcji.

Goudin nie naruszył litery tekstu św. Tomasza opisującego analogię. Jednakże Akwinata w odróżnieniu od Antoine Goudina nie nazywa opisanego orzekania wspólnej nazwy o wielu analogią atrybucji. A zatem to, co św. Tomasz powiedział o analogii jako takiej Goudin nazwał analogią atrybucji. Zredukował tym samym ogólne pojęcie analogii do pojęcia analogii atrybucji. W myśl twierdzenia Goudin'a analogia atrybucji definiuje analogię jako taką. W przedstawionej charakterystyce analogii Goudin wyraźnie postępuje za Kajetanem ignorując uniwersalne znaczenie tego, co na temat analogii jasno powiedział św. Tomasz w Summa Theologiae ${ }^{31}$. Jeśli coś orzeka się o wielu rzeczach analogicznie, to dlatego że to coś, zgodnie z właściwym mu pojęciem, znajduje się w czymś jednym, od czego pozostałe biorą tylko nazwę.

Leclère uważa, że także Jan od św. Tomasza interpretując Akwinaty pojęcie analogii podąża za Kajetanem ${ }^{32}$. Jan od św. Tomasza wskazuje, że spośród wielu warunków analogii atrybucji i proporcji jeden z nich jest szczególny. Otóż wymaga on, aby w analogacie głównym forma realizowała się wewnętrznie w innych zaś zewnętrznie i przez denominację. Znaczy to, że warunek ten jest wspólny dla tych odmian analogii i dlatego definiuje najbardziej uniwersalne pojęcie analogii. Jan od św. Tomasza dostrzega jednak, że zarysowane ogólne pojęcie analogii nie jest doktryną analogii św. Tomasza i dlatego dodaje Fundamentum vero alterius partis est primo ex D. Thomas, qui generaliter docet in omnibus analogis neccesse esse, quod omnia dicantur per respectum ad unum, et quod illud unum ponatur in definitione omnium, ut patet I, q.13, a.6 et I, q. 16, a.6 $6^{33}$. Co się tyczy uniwersalnego pojęcia analogii, to św. Tomasz naucza, że we wszystkich analogiach konieczne jest, aby denominacja dokonywała się przez odniesienie do jednego oraz że to jedno winno być zawarte w definicji każdego.

W gruncie rzeczy pogląd Jana od św. Tomasza, dotycząca Tomaszowego uniwersalnego pojęcia analogii, nie koresponduje z tym, co Akwinata powiedział na temat analogii. Zgodna jest raczej z tym, co na temat analogii powiedział Kajetan. Mimo, iż Jan od św. Tomasza chciał wiernie zrekonstruować św. Tomasza najbardziej ogólne pojęcie analogii, to $\mathrm{w}$ ostateczności imputował św. Tomaszowi tezę Kajetana, iż jego uniwersalnym pojęciem analogii jest analogia atrybucji ${ }^{34}$. Jan od św. Tomasza wzmiankuje, iż św. Tomasz uczy, że w analogiach atrybucji, to co się orzeka powinno się znaleźć wewnętrznie $\mathrm{w}$ jednym $\mathrm{z}$ analogatów, a w innych na sposób orzekania. Jego zdaniem dowodzi tego tekst Summa Theologiae I, q. 16, a. 6, et 4, gdzie św. Tomasz

\footnotetext{
${ }^{31}$ „Sed quando aliquid dicitur analogice de multis, illud invenitur secundum propriam rationem in uno eorum tantum, a quo alia denominantur". Św. Tomasz z Akwinu, Summa Theologiae I, q. 16, a. 6.

${ }^{32}$ „In analogis attributionis seu proportionis ex multis conditionibus illa est praecipua, quod in principali analogato inveniatur forma intrinsece, in aliis vero extrinsece et per denominationem". Jan od św. Tomasza, Cursus philosophicus thomisticus, Log. II P., q. XII, a. 4, cyt. za Abbé S. Leclère, op. cit., przyp. 4.

${ }^{33}$ Ibidem.

${ }^{34}$ „Ita sumitur ex D. Thomas, qui utrumque docet. Nam in istis analogis attributionis debeat tantum invenire intrinsece in uno et denominative in aliis, constat ex I p. q.16, a.6 et 4, Metaph. Lect. 1 et 11, Metaph. Lect.3, ubi ponit formam debere inveniri in uno analogatorum tantum secundum propriam rationem, a quo alia denominantur". Ibidem.
} 
wskazuje, że forma powinna się znajdować tylko w jednym spośród analogatów we właściwym jej pojęciu. Niewątpliwie Jan od św. Tomasza trafnie interpretuje tekst św. Tomasza, poza jednym wiążącym szczegółem, że w tym tekście Akwinata nie charakteryzuje analogii atrybucji, lecz po prostu opisuje analogię jako taką.

W żadnym komentowanym przez Jana od św. Tomasza tekście Akwinata nie nazywa analogią jako taką tego, co Kajetan nazywał analogią atrybucji. Jan od św. Tomasza przekonuje, że w pismach Akwinaty analogia atrybucji reprezentuje najbardziej uniwersalne pojęcie analogii w następujący sposób: Ad primum ex autoritate S. Thomae respondetur, quod in illa universali loquitur $S$. Thomas non de omnibus analogis absolute, sed restrictive de analogis attributionis tantum, quia in illo loco I p., q.13 agit de analogia magis dialectice quam metaphysice, scilicet ut tenet se ex parte nominum, non ex parte rerum. Sicut autem in analogiam metaphysice considerata attenditur inaequalitas in rerum, ita in analogia dialectice considerata attenditur inaequalitas in modo significandi et nominandi $i^{35}$. Zdaniem Leclère komentator błędnie ograniczył św. Tomasza uniwersalne pojęcie analogii do analogii atrybucji. Według Leclère błąd ten mógł się pojawić dlatego, że analogia działa na mocy podobieństwa między faktycznie istniejącymi analogatami (porządek metafizyczny). Tymczasem jego zdaniem nie zwrócono uwagi na to, że przecież podobieństwo $\mathrm{w}$ analogii nie jest determinowane przez rzeczy, lecz przez praktyczny intelekt, który analogicznie orzeka o rzeczach tę samą nazwę na podstawie stosunku proporcji (porządek logiczny). Nie można również przeoczyć, że samo słowo proportio jest w pojęciu analogii analogiczne. Stąd wystarczająca do analogicznego orzekania determinacja proportio należy zawsze do praktycznego intelektu twierdzi Leclère.

Trudno się jednak zgodzić ze stanowiskiem Leclère, który upatruje błąd komentatorski Jana od św. Tomasza $\mathrm{w}$ tym, że przeniósł on dyskusję dotyczącą analogii z porząaku logicznego na teren metafizyki oraz że powielił on błąd Kajetana. Po pierwsze Kajetana analogia atrybucji jest przecież definiowana w kategoriach logicznych. Po drugie Kajetan komentując dzieła św. Tomasza nie utrzymywał, że pojęcie analogii atrybucji jest w myśli Akwinaty najbardziej uniwersalnym i prawdziwym pojęciem analogii ${ }^{36}$. Za takie pojęcie analogii uznał natomiast analogię proporcjonalności właściwej, której charakterystykę odnalazł w traktacie De Veritate $^{37}$. Leclère, broniąc słuszności swojego przekonania co do przeniesienia przez Kajetana istotnego problemu analogii z logiki na teren metafizyki, musiałby wykazać, że problematyka analogii proporcjonalności u Kajetana jest problematyką metafizyczną nie zaś logiczną, co również nie wydaje się być słuszne ze względu na to, że Kajetan ujednoznacznił relacje tworzące analogię proporcjonalności ${ }^{38}$. Tymczasem analogia zasadzająca się na jednoznacznych relacjach z pewnością analogią metafizyczną nie jest.

\section{ZAKOŃCZENIE}

W interpretacji analogii i jej podziału Leclère przyjął, że analogia jako taka winna być badana w kontekście orzekania nazw. Chodzi o porządek użycia tego samego słowa, które

\footnotetext{
${ }^{35}$ Ibidem.

${ }^{36}$ Por. M. A. Krąpiec, op. cit., s. 191.

${ }^{37}$ Por. M. Ciszewski, Kajetan [w:] Powszechna encyklopedia filozofii, red. A. Maryniarczyk i in., t. 5, Polskie Towarzystwo Tomasza z Akwinu, Lublin 2004, s. 428.

${ }^{38}$ Por. M. A. Krąpiec,op. cit., s. 196-197.
} 
per prius jest orzekane o jednej rzeczy i per posterius orzekane o rzeczy innej bez denominacji wewnętrznej, lecz na podstawie jej podobieństwa, bądź jakiegokolwiek stosunku do rzeczy pierwszej ${ }^{39}$. Zdaniem de Leclère to jest właściwe najogólniejsze pojęcie analogii w filozofii św. Tomasza, które z kolei każda odmiana analogii zakłada. Powyższa analiza doprowadziła do wniosku, że Leclère nie dokonał wiernej rekonstrukcji pojęcia analogii jako takiej. W niezgodzie z tekstami św. Tomasza zredukował analogię do porządku logicznego, w porządku logicznym zaś do orzekania wspólnych nazw o wielu przedmiotach. Dokonana przez de Leclère rekonstrukcja Tomaszowego uniwersalnego pojęcia analogii nie odzwierciedla zawartych w jego dziełach, wiążących dla doktryny analogii, głównych twierdzeń św. Tomasza na temat analogii.

\section{LITERATURA}

[1] Cajetan, Scripta philosophica: De nominum analogia, Romae: Inst. "Angelicum", 1952.

[2] Anderson J. F., Reflections on the analogy of being, Martinus Nijhoff, The Hague 1967.

[3] Ciszewski M., Kajetan [w:] Powszechna encyklopedia filozofii, red. A. Maryniarczyk i in., t.5, Polskie Towarzystwo Tomasza z Akwinu, Lublin 2004, 427-429.

[4] Hochschild J., The Semantics of Analogy Reading Cajetan's De Nominum Analogia, University of Notre Dame Press, Indiana 2010.

[5] Krause A., Zur Analogie bei Cajetan und Thomas von Aquin: eine Analyse, Halle/Saale, Hallescher 1999.

[6] Krąpiec M. A., Teoria analogii bytu, RW KUL, Lublin 1993.

[7] Leclère S. Abbé, A propos de l'analogie chez saint Thomas d'Aquin [online], http://www.salve- regina.com/salve/L\%27analogie (30.02.2015).

[8] McInerny R., Aquinas and Analogy, The Catholic University of America Press, Washington, 1996.

[9] McInerny R., The logic of analogy, An interpretation of st Thomas, Martinus Nijhoff, Hague 1961.

[10] Montagnes B., La doctrine de l'analogie de l'être d'après saint Thomas d'Aquin, Publications Universitaires, Louvain 1963.

[11] Owen G. E. L., Logic, Science and Dialectic, Cornell University Press, Ithaca 1986.

[12] Św. Tomasz z Akwinu, De Potentia Dei, q. 10, a. 4.

[13] Św. Tomasz z Akwinu, De Veritate q. 2, a. 11.

[14] Św. Tomasz z Akwinu, III Sent. d. 1, q. 1, a. 1.

[15] Św. Tomasz z Akwinu, In Boetii de Trinitate, p. 3, q. 5, a. 4.

[16] Św. Tomasz z Akwinu, In I Sent. d.19, q. 5, a. 2, ad 1.

[17] Św. Tomasz z Akwinu, Summa contra Gentiles I, 34.

[18] Św. Tomasz z Akwinu, Summa Theologiae I, q. 13, a. 5.

\footnotetext{
${ }^{39}$, Ad primum ergo dicendum quod consuetum est quod nomina a sui prima impositione detorqueantur ad alia significanda, sicut nomen medicinae impositum est primo ad significandum remedium quod praestatur infirmo ad sanandum, deinde tractum est ad significandum artem qua hoc fit”. Św. Tomasz z Akwinu, Summa Theologiae II-II, q. 57, a. 1, ad 1.
} 
[19] Św. Tomasz z Akwinu, Summa Theologiae II-II, q. 57, a. 1, ad 1.

[20]Ziembiński Z., Logika praktyczna, Wydawnictwo PWN, Warszawa 2004.

\section{REKONSTRUCTION OF THE UNIVERSAL CONCEPT OF ANALOGY IN} THE PHILOSOPHY OF ST. THOMAS

The subject of the analysis in present study is the St. Thomas Aquinas' doctrine of analogy. Although the analogy has its permanent place in philosophy and catholic theology, its concept is not the same in the thought of the commentators of St. Thomas. If we want the analogy to be an appropriate tool of philosophical and theological cognition, it should to refute erroneous interpretations of analogy. The author of this study examines the interpretation of the doctrine of analogy of St. Thomas presented by the contemporary French Thomist, S. Leclère. It is the voice in the debate about how St. Thomas understands the universal concept of analogy. This article gives an answer to the question, what is the most universal concept of analogy in the works of St. Thomas, which is present in each kind of analogy. This study shows that Leclère reduces the universal concept of analogy to analogy of names. But Thomas repeats in many of his expressions that the main concept of analogy belongs to the metaphysical order and not to the logical order. For this reason, the reconstruction of the most universal concept of analogy should be done at the level of metaphysical order, contrary to this, as does Leclère, which binds the notion of universal analogy with logical order. On the other hand Leclère rightly opposes the reduction of the universal concept of analogy to the one of the kinds of analogy of names, as had done Cajetan and all commentators of St. Thomas who followed in his footsteps.

Keywords: analogy, analogous predication, language, metaphysics, Thomism.

DOI:10.7862/rz.2016.hss.50

Przesłano do redakcji: czerwiec 2016

Przyjęto do druku: wrzesień 2016 